Egyptian Journal of Aquatic Biology \& Fisheries

Zoology Department, Faculty of Science,

Ain Shams University, Cairo, Egypt.

ISSN $1110-6131$

Vol. 25(4): 628 - 642 (2021)

www.ejabf.journals.ekb.eg

\title{
The Relationship between Plankton Abundance and Abiotic Parameters in the Downstream Section of the Musi River, Palembang
}

\author{
Rudy Sugiharto ${ }^{1}$, Agus Tjahjono ${ }^{2 *}$ \\ ${ }^{1}$ Nautical Studies Department; Inland Waters and Ferries Transport, Polytechnic of Palembang \\ (Politeknik Transportasi Sungai, Danau dan Penyeberangan Palembang), Sabar Jaya 116, \\ Perajen, Banyuasin Regency, Palembang, South Sumatera, Indonesia. \\ ${ }^{2}$ Engineering Department; Inland Waters and Ferries Transport, Polytechnic of Palembang \\ (Politeknik Transportasi Sungai, Danau dan Penyeberangan Palembang), Sabar Jaya 116, \\ Perajen, Banyuasin Regency, Palembang, South Sumatera, Indonesia.
}

*Corresponding Author: rudysugihartosdp@gmail.com

\begin{abstract}
ARTICLE INFO
Article History:

Received: April 26, 2021

Accepted: June 21, 2021

Online: Aug. 30, 2021

\section{Keywords: Musi river, phytoplankton and zooplankton, diversity $\left(\mathrm{H}^{\prime}\right)$, uniformity $(\mathrm{E})$, dominance (D), ANOVAand PCA methods.}

Downstream section of

The Musi River, the largest river in Palembang in South Sumatera, has become one of its important sites, in which various activities such as shipping and irrigation are performed. Those activities are assumed to eventually affect the fertility of the waters. This research was conducted to accomplish three targets. The first was to analyze the abundance, diversity index ( $\left.\mathrm{H}^{\prime}\right)$, uniformity (E), and the dominance of phytoplankton and zooplankton. The second target was to examine the difference in abundance of phytoplankton and zooplankton in the stations using ANOVA. The third was to analyze the relationship between the abundance of phytoplankton and zooplankton using PCA (Principal Component Analysis). Results revealed that the phytoplankton found downstream of the Musi River consisted of four classes. Bacillariophyceae, for instance, dominated the waters with a rate of $51.35 \%$, followed by Chlorophyceae with a rate of $33.58 \%$ and the other two classes. The zooplankton consisted of twelve classes whose dominant class was Cilliate reaching $36.56 \%$ and followed by Mastigophora of $14.7 \%$. It was also discovered that the diversity index $\left(\mathrm{H}^{\prime}\right)$ of plankton was moderate. Results indicate that the water condition was somewhere in between moderately and heavily polluted. The uniformity index (E) was high while the level of dominance (D) indicates that there was no dominant genus in the waters. Moreover, based on ANOVA, the abundance of plankton in the stations showed no significant differences. In addition, the abundance of zooplankton was influenced by four factors whose largest contribution was nitrite, TSS, and fosfat reaching $37.2 \%$.
\end{abstract}

\section{INTRODUCTION}

The Musi River is one of the large rivers in South Sumatera located in three provinces: Bengkulu, Jambi, and South Sumatera. It consists of upstream, middle and downstream sections. The downstream, reaching $146 \mathrm{~km}$, starts from Tebing Abang village, Muara 
Enim Regency, to the mouth of Bangka Strait (Fisheries Ecological Survey Team, 1977; Wiadnyana \& Husnah, 2011). This river has become the lifeblood of Palembang citizens as their means of transportation, housing and settlement, and fishing site as well (Eddy, 2013).

The mouth of Musi river acts as a fish resource with biomass reaching 24.5-105.47 $\mathrm{kg} / \mathrm{km}^{2}$ (Prianto \& Suryati, 2010). The estuary is functioned as an ecosystem, spawning, and nursery ground for fish larvae. Thus, numbers of marine or fresh fish move to these waters (Prianto et al., 2013). However, in terms of the physical habitat of the river, based on both riverbed subtract and factors affecting the river health, the waters around Sebrang Ulu I and II tend to be in bad conditions (Trisnaini et al., 2018).

Remarkably, plankton are biotic organisms floating in waters. They consist of phytoplankton which are the plantlike community of plankton and zooplankton which are the animal-like community of plankton. Phytoplankton have chlorophyll and are several microns in size. Their lives depend on water movement which can indicate the quality of local waters (Harmoko \& Krisnawati, 2017). Based on the saprobic status, the downstream of the Musi River is classified as lightly to moderately polluted while the other downstream sections, Kertapati and Gandus areas, show moderate to severe levels of pollution (Zulkifli et al., 2009; Meiwinda et al., 2015). The phytoplankton found around Salah Nama Island are categorized as moderate (Dwirastina \& Riani, 2019).

A research conducted on Musi River's tributary, Komering River, reported that tenclasses of phytoplankton were found with Bacillariophyceae as the most dominant class. Moreover, the research also showed that the diversity index was moderate, dominant phytoplankton species was found, and the physico-chemical parameters were regarded as stable (Tawanggian et al., 2020). The Skeletonema genera had experienced an explosive population growth reaching $98.71 \%$ of the total population at the mouth of Banyuasin estuary. This condition indicated an increase in nutrients on the coast (Aryawati et al., 2018).

Hence, the current research aimed: (1) to analyze the abundance, diversity index $\left(\mathrm{H}^{\prime}\right)$, uniformity (E), and dominance of phytoplankton and zooplankton; (2) to examine the difference in abundance of phytoplankton and zooplankton in the stations using ANOVA, and (3) to analyze the relationship between phytoplankton and zooplankton abundance using PCA (Principal Component Analysis).

\section{MATERIAL AND METHODS}

The research field was carried out in the waters of the downstream section of the Musi River, Palembang, and South Sumatera Province, Indonesia in July 2019 at high tide. Random sampling was performed at six observation points: (1) the first point, located in Ampera bridge $\left(02^{0} 59^{\prime} 25^{\prime \prime} \mathrm{S}, 104^{0} 45^{\prime} 55^{\prime \prime} \mathrm{E}\right)$; (2) the second point, in Boom Baru port $\left(02^{0} 58^{\prime} 55^{\prime \prime} \mathrm{S}, 104^{0} 46^{\prime} 44^{\prime \prime} \mathrm{E}\right)$; (3) the third point, located in Sriwijaya fertilizer factory 
$\left(02^{0} 59^{\prime} 05^{\prime \prime} \mathrm{S}, 104^{0} 47^{\prime} 46^{\prime \prime} \mathrm{E}\right)$; (4) the fourth point, in Pertamina's refinery jetty $\left(02^{0} 59^{\prime}\right.$ $21^{\prime \prime} \mathrm{S}, 104^{0} 50^{\prime} 03^{\prime \prime} \mathrm{E}$ ); (5) the fifth point, in a shipyard owned by Mariana Bahagia Company $\left(02^{0} 58^{\prime} 02\right.$ "S, $\left.104^{0} 52^{\prime} 12^{\prime \prime} \mathrm{E}\right)$, and the sixth point, in the shrimp processing area and SAP's palm oil mill ( $02^{0} 57^{\prime} 30^{\prime \prime} \mathrm{S}, 104^{0} 52^{\prime} 44^{\prime \prime}$ E) (Fig. 1).

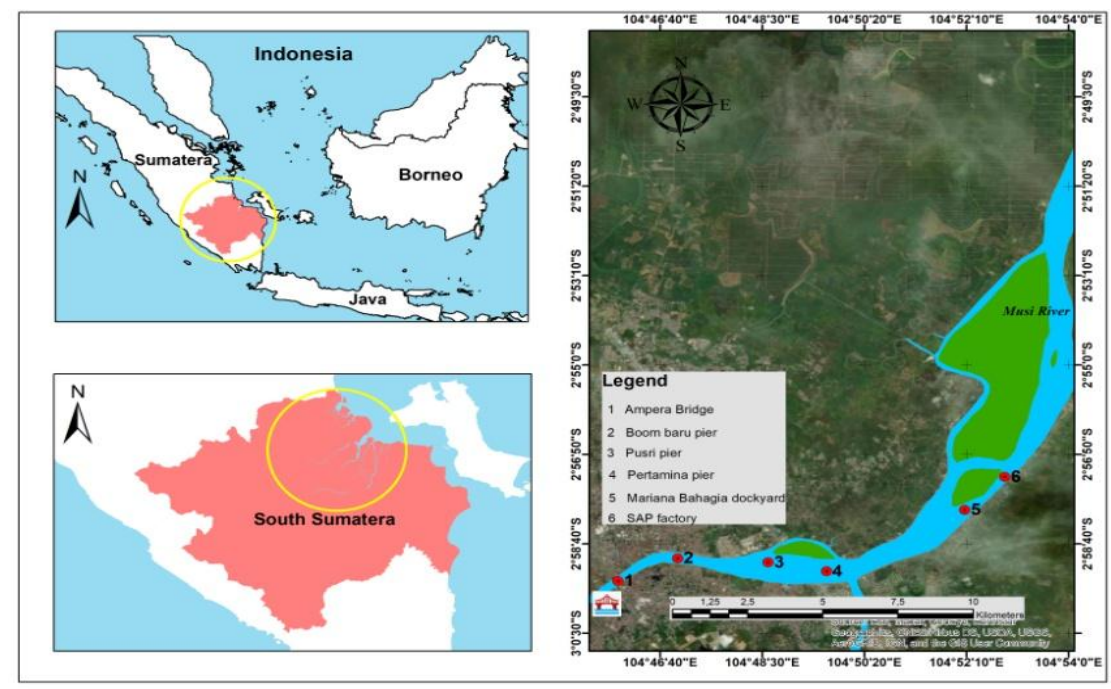

Fig. 1. Research sites.

Thirteen parameters were studied ranging from physical to chemical parameters that affected the abundance of phytoplankton and zooplankton. The physical parameters included temperature, turbidity, and current velocity. The chemical parameters included TDS (Total Dissolved Solid), TSS (Total Suspended Solid), salinity, nitrate, nitrite, pH, phosphate, BOD (Biological Oxygen Demand), and DO (Dissolved Oxygen). Besides, another parameter that affected the photosynthesis of aquatic organism was depth. While, water temperature, TDS, and the $\mathrm{pH}$ values were identified using HM Digital COM-300. Water salinity was studied using Saltmeter CT-3080, whereas the water turbidity was measured by the WGZ-1B Portable Turbidity Meter. On the other hand, the parameters of TSS, nitrate, nitrite, phosphate, BOD, and DO were studied at Industrial Research and Standardization Centre of Palembang. The current velocity measurement was performed using FL 03 Flow watch. The position of each station was identified and determined using Garmin eTrex 30x type GPS device, whereas water depth was measured using a measuring line.

The abundance of phytoplankton and zooplankton was analyzed using APHA formula, while the level of diversity was examined using Shannon-Wiener diversity index $\left(\mathrm{H}^{\prime}\right)$ (APHA, 1989; Odum, 1996). The diversity index value can be classified into three categories: (a) $H^{\prime}<1=$ low diversity and low community stability, (b) $1 \leq \mathrm{H} " \leq 3=$ medium diversity and moderate community stability, and (c) $\mathrm{H}^{\prime}>3$ = high diversity and high community stability (Odum, 1996). The uniformity index (E) was calculated using Poole formula, where $\mathrm{E}$ ranges from $0-1$. $\mathrm{E}>0.6$ indicates a high uniformity of species. $0.6 \geq \mathrm{E}$ 
$\geq 0.4$ indicates a medium uniformity. $\mathrm{E}<0.4$ means that the uniformity of species is low (Odum, 1996; Supono, 2008). Simpson's index of dominance (D) was applied to determine the dominance of certain species in waters. Dominance index between $0-1 ; \mathrm{D}=$ 0 , means that there are no dominant species or the community structure is stable while D $=1$, indicates that dominant species exist or the community structure is unstable due to ecological pressure (Odum, 1996; Kartika et al., 2015).

In this research, the data were tested using One Way Anova in order to determine the existence of the statistically significant differences between the means of two or more independent groups. The tests which can be performed on the output are Homogeneity of Variances, ANOVA, and Post Hoc (Tukey HSD and Bonferroni Test) (Santoso, 2015). The research data included the abundance of phytoplankton and zooplankton at the six stations. The hypothesis stated that, $\mathrm{H}_{0}=$ abundance of phytoplankton/zooplankton at six stations was the same and $\mathrm{H}_{1}=$ abundance of phytoplankton/zooplankton at six stations was different.

The data including the abundance of phytoplankton, zooplankton, temperature, TDS, salinity, TSS, nitrite, nitrate, phosphate, BOD, DO, and turbidity were analyzed using PCA processed with IBM SPSS Statistics 25 . The PCA analysis is accessed by grouping the data statistics to identify the relationship between phytoplankton and zooplankton abundance using chemical physics parameters (Arazi et al., 2019). Factor analysis can also be used to determine the correlation matrix of respondents based on their characteristics (Ghozali, 2013). The PCA is used to summarize the correlation pattern between variables, reduce a number of variables into small factors, provide operational definitions of the main dimensions of the use of observed variables, and test the underlying theory (Umar, 2009; Tabachnickand Fidell, 2019).

\section{RESULTS AND DISCUSSION}

Phytoplankton are identified as microscopic organisms which float in waters. They consist of five major groups: Cyanophyta (blue algae), Chlorophyta (green algae), Chrysophyta (yellow algae), Pyrophyta, and Euglenophyta (Nybakken, 1992; Asriyana \& Yuliana, 2012). In the downstream section of the Musi River, four classes of phytoplankton were found: Bacillariophyceae, Chlorophyceae, Cyanophyceae, and Dinophyceae. Some genera of each class were also found: 17 genera of Bacillariophyceae, 11 genera of Chlorophyceae, 3 genera of Cyanophyceae and only one genera of Dinophyceae (Table 1).

The abundance of phytoplankton ranged between 456.11 and 958.4 individual/1. The highest abundance was found at the refinery jetty at the estuary of Komering River, while the lowest was found at Boom Baru port. The abundance was dominated by Bacillariophyceae class with a dominance rate of $51.35 \%$, followed by the Chlorophyceae class by $33.58 \%$, and the rest were Cyclotella and Dinophyceae. This 
finding corresponds to that of Bahri (2005) who reported that, the most dominant plankton were Bacillariophyceae and Chlorophyceae, and added that zooplankton of Rotifera class were higher in numbers than those of Copepoda and Cladocera classes. The dominance rate of Bacillariophyceae reached $98.33 \%$ followed by Chlorophyceae which were also found in the waters of Bangka Strait (Isnaini et al., 2014). The abundance of Bacillariophyceae class was attributed to the ability to adapt to the environmental conditions (Munthe et al., 2012).

Table 1. The abundance of phytoplankton in the downstream section of the Musi River

\begin{tabular}{|c|c|c|c|c|c|c|c|}
\hline \multirow{2}{*}{ No. } & \multirow{2}{*}{ Class/Genera } & \multicolumn{6}{|c|}{ Station } \\
\hline & & 1 & 2 & 3 & 4 & 5 & 6 \\
\hline \multicolumn{8}{|c|}{ Bacillariophyceae } \\
\hline 1 & Amphora & 5.67 & 11.22 & 0 & 0 & 0 & 0 \\
\hline 2 & Bacillaria & 16.67 & 11 & 41.67 & 33.34 & 108.17 & 58.34 \\
\hline 3 & Cocconeis & 0 & 0 & 0 & 16.67 & 8.34 & 8.34 \\
\hline 4 & Cyclotella & 33.56 & 11.22 & 0 & 0 & 16.84 & 0 \\
\hline 5 & Fragillaria & 0 & 22.33 & 0 & 0 & 0 & 0 \\
\hline 6 & Fragillaria & 27.78 & 0 & 8.34 & 58.34 & 41.67 & 41.84 \\
\hline 7 & Gunardia & 55.78 & 27.78 & 25.17 & 0 & 74.84 & 41.84 \\
\hline 8 & Gyrosigma & 0 & 0 & 0 & 16.67 & 0 & 0 \\
\hline 9 & Melosira & 0 & 0 & 0 & 0 & 8.5 & 0 \\
\hline 10 & Navicula & 78 & 61 & 41.5 & 83.34 & 41.67 & 16.5 \\
\hline 11 & Nitzchia & 83.33 & 72.33 & 41.5 & 91.67 & 83.17 & 58.5 \\
\hline 12 & Pinnularia & 0 & 28 & 33.5 & 8.34 & 0 & 41.67 \\
\hline 13 & Rhizosolenia & 0 & 11 & 0 & 0 & 0 & 0 \\
\hline 14 & Skeletonema & 0 & 11.11 & 8.5 & 0 & 0 & 16.5 \\
\hline 15 & Surirella & 16.67 & 16.67 & 58.34 & 75 & 50 & 58.17 \\
\hline 16 & Tabellaria & 5.67 & 22.22 & 8.34 & 0 & 0 & 0 \\
\hline 17 & Triceratium & 5.67 & 5.67 & 0 & 0 & 0 & 0 \\
\hline \multicolumn{8}{|c|}{ Chlorophyceae } \\
\hline 18 & Actinastrum & 0 & 0 & 0 & 75 & 0 & 0 \\
\hline 19 & Ankistrodesmus & 33.33 & 0 & 0 & 16.67 & 8.34 & 0 \\
\hline 20 & Clostrerium & 11 & 0 & 16.67 & 0 & 0 & 0 \\
\hline 21 & Coelastrum & 0 & 0 & 0 & 0 & 0 & 8.34 \\
\hline 22 & Coscinodiscus & 133.33 & 11 & 0 & 0 & 0 & 16.5 \\
\hline 23 & Microspora & 0 & 0 & 0 & 8.34 & 8.5 & 0 \\
\hline 24 & Oocytis & 0 & 0 & 0 & 8.34 & 8.34 & 0 \\
\hline 25 & Pediastrum & 0 & 0 & 8.5 & 0 & 0 & 0 \\
\hline 26 & Scenedesmus & 5.67 & 0 & 8.5 & 8.34 & 8.5 & 0 \\
\hline
\end{tabular}




\begin{tabular}{cccccccc}
27 & Spiroghyra & 0 & 105.67 & 125.17 & 233.33 & 225 & 250 \\
\hline 28 & Monoraphidium & 0 & 0 & 8.34 & 0 & 0 & 0 \\
\hline Cyanophyceae & & & & & & \\
\hline 29 & Chroococcus & 5.67 & 0 & 0 & 8.34 & 8.5 & 0 \\
\hline 30 & Microcytis & 0 & 16.67 & 8.34 & 0 & 0 & 0 \\
\hline 31 & Oscillatoria & 44.33 & 0 & 75.17 & 200 & 116.67 & 41.84 \\
\hline & Dinophyceae & & & & & & \\
\hline 32 & Prorocentrum & 11.22 & 11.22 & 0 & 16.67 & 16.84 & 25 \\
\hline & Genera & 17 & 16 & 13 & 17 & 17 & 14 \\
\hline & Total & 573.35 & 456.11 & 517.55 & 958.4 & 833.89 & 683.38 \\
\hline
\end{tabular}

The present findings showed the existence of eleven classes of zooplankton. The classes included Ciliates, Rotifers, Crustaceans, Eurotatoria, Tubulinea, Brachiopoda; while Mastigophora classess, included Oligophmenophorea, Monogononta, Tentaculata, and Hexanauplia. Moreover, in each class, there was only one genera found. The abundance of zooplankton ranged from 6.5 to11.64 ind/l and the highest abundance was found at Boom Baru port. The Ciliates class was the most dominant reaching $36.56 \%$, followed by Mastigophora class 14.7\%, and Rotifers 10.94\% (Table 2).

The abundance of plankton in the downstream waters of the Musi River was relatively low and fluctuated. The abundance often included Cladocera, Copepoda, and Rotifera groups ( Adjie, 2007; Prianto et al., 2008; Samuel et al., 2013).

Table 2. The abundance of zooplankton in the downstream section of Musi River

\begin{tabular}{|c|c|c|c|c|c|c|c|}
\hline \multirow{2}{*}{\multicolumn{2}{|c|}{ No. Genera/Class }} & \multicolumn{6}{|c|}{ Station } \\
\hline & & 1 & 3 & 4 & 5 & 6 & 7 \\
\hline \multicolumn{8}{|c|}{ Ciliates } \\
\hline 1 & Cyclops & 0.33 & 0.33 & 0 & 1 & 0.5 & 0.5 \\
\hline 2 & Eudiaptomus & 0.67 & 0.33 & 0 & 0.5 & 0 & 1 \\
\hline 3 & Tintinopsis & 2.33 & 4.33 & 3 & 2.5 & 2.5 & 3.5 \\
\hline 4 & Favella & 0 & 0.33 & 0.5 & 0 & 0.5 & 0 \\
\hline \multicolumn{8}{|c|}{ Rotifers } \\
\hline 3 & Brachionus & 0.33 & 0.67 & 0.5 & 1.5 & 1 & 0 \\
\hline 4 & Keratella & 1 & 0.33 & 0.5 & 0 & 0 & 0 \\
\hline \multicolumn{8}{|c|}{ Crustaceans } \\
\hline 5 & Acartia & 0.67 & 0.33 & 0.5 & 0 & 0 & 0 \\
\hline 6 & Calanus & 0.33 & 0.33 & 0 & 0 & 0 & 0 \\
\hline \multicolumn{8}{|c|}{ Eurotatoria } \\
\hline 7 & Asplanchna & 0 & 0.33 & 1 & 0 & 0.5 & 0.5 \\
\hline & Argonotholca & 0 & 0 & 0.5 & 0 & 0.5 & 0 \\
\hline
\end{tabular}




\begin{tabular}{|c|c|c|c|c|c|c|}
\hline \multicolumn{7}{|l|}{ Tubulinea } \\
\hline 9 Hyalosphenia & 0 & 1 & 0 & 0 & 0 & 0.5 \\
\hline 10 Centropyxis & 0 & 0.33 & 0 & 0 & 0.5 & 0 \\
\hline \multicolumn{7}{|l|}{ Branchiopoda } \\
\hline 11 Bosmina & 0 & 0.33 & 0 & 0 & 0 & 0 \\
\hline 12 Diaphanosoma & 0 & 0 & 0 & 0 & 0 & 0.5 \\
\hline \multicolumn{7}{|l|}{ Mastigophora } \\
\hline 13 Difflugia & 0.67 & 2.67 & 1 & 1 & 0.5 & 2 \\
\hline \multicolumn{7}{|l|}{ Oligohymenophorea } \\
\hline 14 Paramecium & 1.33 & 0 & 0.5 & 0.5 & 0 & 2 \\
\hline \multicolumn{7}{|l|}{ Monogononta } \\
\hline 15 Conochiloides & 0 & 0 & 0 & 0.5 & 0 & 0 \\
\hline \multicolumn{7}{|l|}{ Tentaculata } \\
\hline 16 Notholca & 0 & 0 & 0 & 0 & 0 & 1 \\
\hline \multicolumn{7}{|l|}{ Hexanauplia } \\
\hline 17 Diaptomus & 0 & 0 & 0 & 0 & 0 & 0.5 \\
\hline Genera & 9 & 13 & 9 & 7 & 8 & 9 \\
\hline Total & 7.66 & 11.64 & 8 & 7.5 & 6.5 & 12 \\
\hline
\end{tabular}

The diversity index $\left(\mathrm{H}^{\prime}\right)$ of phytoplankton ranged between 2.02 and 2.21, and the highest was at the fourth point; the refinery jetty. This finding showed that the diversity of phytoplankton was moderate. The uniformity index (E) ranged between 0.81 and 0.9 ; and the highest was at Boom Baru port, while the lowest was in the shipyard area. Moreover, uniformity indices of all stations were high. The dominance level (D) of phytoplankton ranged between 0.15 and 0.19 , and the highest was found in the shipyard area, while the lowest was found at the other stations. It was also found that all stations show no dominant genera (Fig. 2).

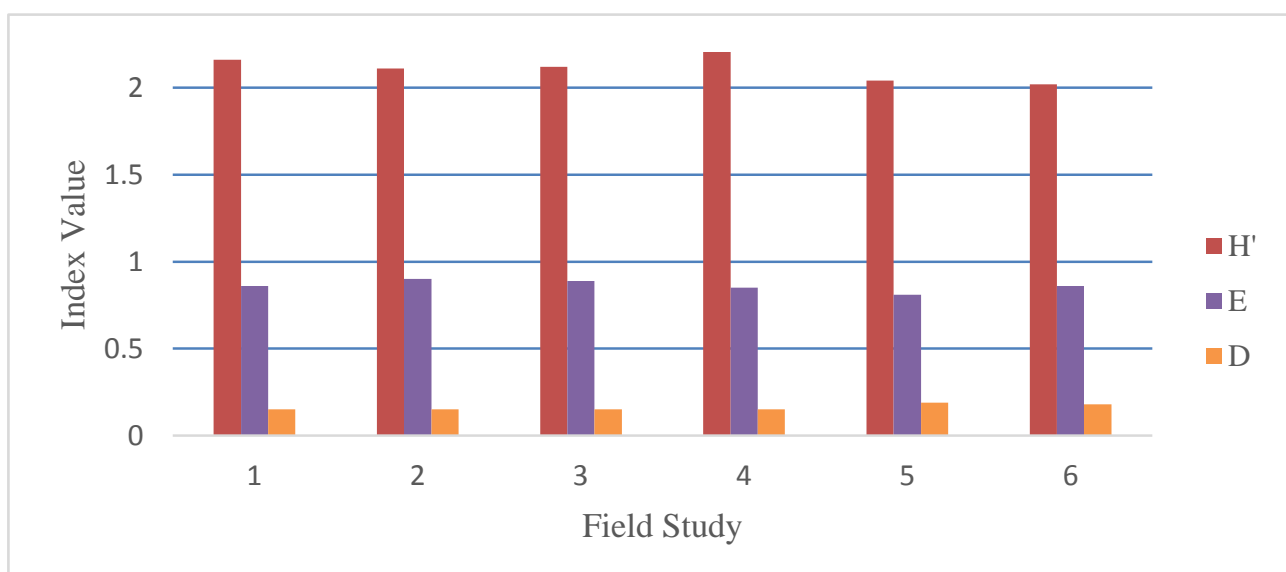

Fig. 2. Phytoplankton's diversity, uniformity and dominance 
The average diversity index $\left(\mathrm{H}^{\prime}\right)$ of zooplankton was 1.58 , ranging from 1.46 and 1.85; the highest diversity was found in the palm oil mill, while the lowest was found around the Ampera bridge. The diversity index of zooplankton was moderate. It means that the waters were moderately to heavily pollute. The findings showed that the uniformity index (E) was 0.89 and 0.95 ; the highest uniformity was obtained in the shipyard while the lowest was found in Boom Baru port. It showed that all stations had high uniformity of zooplankton. The dominance index (D) ranged from 0.19 to 0.26 . The highest was found at the refinery jetty while the lowest was found in the fertilizer factory. The dominance index of all stations showed no dominant genera (Fig. 3).



Fig. 3. Zooplankton's diversity, uniformity and dominance

Additionally, it was found that water temperature ranged from 34.33 to $38.67^{\circ} \mathrm{C}$; the highest temperature was in the palm oil mill. Water temperature for phytoplankton and zooplankton ranged, respectively, from $25-30^{\circ} \mathrm{C}$ and $15-35^{\circ} \mathrm{C}$ (Kadir et al., 2015). The findings showed a temperature distribution which exceeded deviation 3 and was heterogeneous; the condition was not optimum temperature for phytoplankton growth but on the other hand, it was good for zooplankton growth.

According to water quality standard, the downstream water of the Musi River, starting from Jaran Strait to the estuary, was categorized as class III as the water was used for freshwater culture, livestock, and irrigation (Regulation of the Governor of South Sumatera Province No.16 of 2005). The TDS ranged from 38.9 to $41.57 \mathrm{mg} / \mathrm{l}$ and the highest was found at station 6. On the other hand, the TSS ranged from 0.23 to $0.63 \mathrm{mg} / \mathrm{l}$ and the highest was found at station 1. The TDS and TSS values still met the quality standard (1000 and $400 \mathrm{mg} / \mathrm{l})$. It was also found that the salinity was $0.04 \mathrm{ppt}$ which indicates that the downstream was not affected by the sea. Moreover, the nitrite was 0.05 $0.26 \mathrm{mg} / \mathrm{l}$ and the highest was at station 3. On the other hand, the nitrate ranged from 4.88 to $12.5 \mathrm{mg} / \mathrm{l}$ and the highest was found at station 3 .The nitrate content exceeded the water 
quality standard (0.008 mg/l) (Decree of Minister of Environment No.15 of 2004) (Table 3).

Based on the findings, the $\mathrm{pH}$ value reached 5.12-5.25 which was not an optimum $\mathrm{pH}$ for biota. This acidic water was influenced by the open land in the upstream including palm oil plantations, the activities of palm oil industry, and the surrounding community (Soraya et al., 2014). It was also found that the phosphate ranged from 0.1 to $0.28 \mathrm{mg} / \mathrm{l}$ and the highest finding was at station 2. This value exceeded the quality standard. This finding is in accordance with a previous research conducted on Banyuasin river estuary which showed that the phosphate and nitrate content exceeded the quality standard due to the influence of the river upstream (Aryawati et al., 2017).

The BOD ranged from 8.33 to $14.67 \mathrm{mg} / \mathrm{l}$, the highest and lowest was found at stations 4 and 2 . The BOD values were below the quality standard for biota which was $20 \mathrm{mg} / \mathrm{l}$, and the condition was not suitable for biota.

It was found that the DO reached 7.01-7.25 mg/l and the highest was found at stations 5 and 6. If the DO content was $>5 \mathrm{mg} / \mathrm{l}$, it was good for plankton due to the high phytoplankton abundance (Ulqodryet al., 2010; Dewanti et al., 2018). The high content of the DO is possibly caused by the household waste. The turbidity ranged between 24.43 and 59.7 and the highest NTU (Nephelometric Turbidity Units) was found at station 4, indicating that it exceeded the quality standard (value $<5 \mathrm{mg} / \mathrm{l}$ ). Moreover, some parameters exceeded quality standards for biota: temperature, nitrate, $\mathrm{pH}, \mathrm{BOD}$, and turbidity. On the other hand, the content of the TDS, the TSS, and the nitrite still met the quality standard.

Table 3. Physical and chemical quality of downstream section of Musi River (Mean\& SD)

\begin{tabular}{lcccccc}
\hline \multirow{2}{*}{ Parameter } & \multicolumn{5}{c}{ Sampling Field } \\
\cline { 2 - 7 } & 1 & 2 & 3 & 4 & 5 & 6 \\
\hline Temperature $\left({ }^{0} \mathrm{C}\right)$ & $32 \pm 2.72$ & $34 \pm 1$ & $35.27 \pm 1.1$ & $34.33 \pm 1.4$ & $38.53 \pm 1.05$ & $38.67 \pm 1.53$ \\
\hline TDS $(\mathrm{mg} / \mathrm{l})$ & $38.5 \pm 1.22$ & $37.43 \pm 0.23$ & $37.7 \pm 0.26$ & $38.9 \pm 0.1$ & $41.57 \pm 2.48$ & $41.57 \pm 0.35$ \\
\hline Salinity $(\mathrm{ppt})$ & $0.04 \pm 0$ & $0.04 \pm 0$ & $0.04 \pm 0$ & $0.04 \pm 0$ & $0.04 \pm 0$ & $0.04 \pm 0$ \\
\hline TSS $(\mathrm{mg} / \mathrm{l})$ & $0.63 \pm 0.49$ & $0.27 \pm 0.12$ & $0.5 \pm 0.2$ & $0.33 \pm 0.25$ & $0.3 \pm 0.1$ & $0.23 \pm 0.06$ \\
\hline Nitrite $(\mathrm{mg} / \mathrm{l})$ & $0.16 \pm 0.03$ & $0.19 \pm 0.05$ & $0.26 \pm 0.18$ & $0.11 \pm 0.08$ & $0.05 \pm 0.02$ & $0.1 \pm 0.07$ \\
\hline Nitrate $(\mathrm{mg} / \mathrm{l})$ & $11.01 \pm 1.99$ & $4.88 \pm 6.42$ & $12.5 \pm 9.47$ & $10.38 \pm 7.97$ & $10.44 \pm 1.47$ & $10.8 \pm 1.92$ \\
\hline pH & $5.12 \pm 0.18$ & $5.16 \pm 0.19$ & $5.15 \pm 0.21$ & $5.22 \pm 0.19$ & $5.21 \pm 0.22$ & $5.25 \pm 0.18$ \\
\hline Phosphate $(\mathrm{mg} / \mathrm{l})$ & $0.22 \pm 0.19$ & $0.28 \pm 0.22$ & $0.15 \pm 0.05$ & $0.12 \pm 0.03$ & $0.11 \pm 0.06$ & $0.1 \pm 0.03$ \\
\hline BOD $(\mathrm{mg} / \mathrm{l})$ & $11.67 \pm 3.21$ & $14.67 \pm 5.69$ & $11 \pm 3.46$ & $8.33 \pm 7.51$ & $10 \pm 5.2$ & $11 \pm 2.65$ \\
\hline DO $(\mathrm{mg} / \mathrm{l})$ & $7.04 \pm 0.6$ & $7.09 \pm 0.1$ & $7.01 \pm 0.1$ & $7.13 \pm 0.16$ & $7.25 \pm 0.17$ & $7.25 \pm 0.19$ \\
\hline Turbidity $(\mathrm{NTU})$ & $34.13 \pm 5.25$ & $24.43 \pm 0.51$ & $25.77 \pm 1.25$ & $59.07 \pm 50.87$ & $24.77 \pm 0.7$ & $33.6 \pm 7.3$ \\
\hline Current speed $(\mathrm{m} / \mathrm{s})$ & 0.2 & 0.16 & 0.17 & 0.11 & 0.41 & 0.28 \\
\hline Depth $(\mathrm{m})$ & 0.14 & 10.8 & 0.2 & 1.1 & 7.7 & 6.9 \\
\hline
\end{tabular}


Based on the difference test on phytoplankton abundance found in the stations using One Way Anova, it was found that the average abundance of stations 1 - 6 was 20.95 ind/l which included 192 data. The minimum abundance was found at station 2 and the maximum was at station 4 . The hypothesis of this research said that $\mathrm{H}_{0}=$ the abundance of phytoplankton at six stations was the same while $\mathrm{H}_{1}=$ the abundance of phytoplankton at six stations was different. According to Levene test, the statistics showed that the values were 2,$624 ; 0.771 ; 0.771$; and 1.608 with the probability values that reached 0.26 ; $0.571 ; 0.572$; and 0.16 . If each probability was $>0.05$ then $\mathrm{H}_{\mathrm{o}}$ was true; meaning that the abundance of phytoplankton at the six stations was the same. By comparing $\mathrm{F}_{\text {statistic }}$ with


meaning that the abundance of phytoplankton at the six stations was the same.

On the other hand, based on the comparison test on zooplankton abundance found in stations using One Way Anova, it was found that the average abundance of stations 1 - 6 was $0.47 \mathrm{ind} /$ liter which included 114 data. The minimum abundance was found at station 5 and the maximum was at station 2 . The hypothesis of this research said that $\mathrm{H}_{0}=$ the abundance of zooplankton at six stations was the same while $\mathrm{H}_{1}=$ the abundance of zooplankton at six stations was different. According to Levene test, the statistics showed that the values were $0.763 ; 0.305 ; 0.305$; and 0.363 with the probability values that reached $0.579 ; 0.909 ; 0.909$; and 0.873 . If each probability was $>0.05$ then $\mathrm{H}_{0}$ was true; meaning that the abundance of zooplankton at the six stations was the same. By comparing $F_{\text {statistic }}$ with $F_{\text {table, assuming that }} F_{\text {output }}<F_{\text {table, }}$, it was found that $0.456<2.21$ then $\mathrm{H}_{\mathrm{o}}$ was accepted; meaning that the abundance of zooplankton at the six stations was the same.

There were 12 variables tested using PCA: the abundance of phtytoplankton, the abundance of zooplankton, temperature, TDS, TSS, nitrate, nitrite, $\mathrm{pH}$, phosphate, BOD, DO, and turbidity. Nine variables met the requirements with eigenvalues $>1$ including temperature, TDS, TSS, nitrate, nitrite, phosphate, DO, turbidity, and the abundance of zooplankton. KMO (Kaiser-Meyer-Olkin) test resulted in value of 0.587 which means that the factor analysis could be done and has met the requirements. The findings also showed that the four factors which influenced the results were found with a total contribution of $82.23 \%$ resulted from $37.2 \%, 15.95 \%, 15.7 \%$, and $13.39 \%$. The four factors had positive correlation and the value was $>0.5$ including factor 1 up to factor 4 . Factor 1 included nitrite, TSS, phosphate, and zooplankton abundance; factor 2 was TSS; factor 3 was TDS; and factor 4 was zooplankton abundance.

Factor 1 was labelled as chemical and biotic parameter; factor 2 was physical parameter 1. Factor 3 was labelled as physical parameter 2 while factor 4 was the primary producer biotic factor. The zooplankton abundance was influenced by four factors and the largest contribution was factor 1 reaching $37.2 \%$, including the nitrite, TSS, and 
phosphate. TSS and TDS (factors 2 and 3) evenly influenced the results reaching $15.59 \%$ and $15.7 \%$ while the rest (zooplankton abundance) was only $13.39 \%$ (Fig. 4).

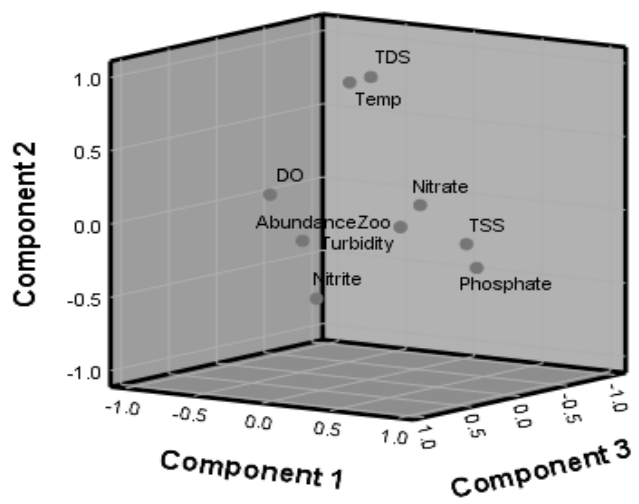

Fig. 4. The graph of PCA

On the other hand, some factors were negatively correlated: factor 1 (DO), factor 2 (DO), factor 3 (nitrate), and factor 4 (turbidity). It means that the higher the DO and nitrate content were, the lower the abundance of zooplankton. This condition could cause a greater phytoplankton population. A very significant contribution of factor 1 came from nitrite (0.81); TSS's contribution was fairly significant (0.7); the phosphate's (0.53) and zooplankton's abundances (0.52) were moderate. A research conducted at Sugihan estuary showed a distribution in river water consisting of light intensity, temperature, nitrate, phosphate, Pleurosigma and Pseudo-nitzschia (Mulyadi et al., 2019).

Water fertility which included the abundance of Belida fish was influenced by the presence of plankton, including genera Ulothrix, Mytilina and abiotic factors, including TDS, electrical conductivity, waters temperature, chlorophyll-a, flow rate, BOD, DO, pH, alkalinity, and the absence of $\mathrm{CO}_{2}$ (Wibowo et al., 2009). This water fertility was beneficial for phytoplankton in order to perform photosynthesis (Purnamaningtyas $\boldsymbol{e t}$ al., 2017). Research conducted in Sungsang, the estuary of Banyuasin River, which applied PCA found that phytoplankton biodiversity was characterized by diversity index, uniformity, dominance, phosphate, abundance, temperature, $\mathrm{pH}$ and salinity (Pratama $\boldsymbol{e t}$ al., 2019). The high abundance of Baccilariaphyceae positively correlated with the DO chemical parameters. However, it negatively correlated with phosphate (Ismunarti, 2013). The fish abundance in this estuary was influenced by salinity, ammonia, and the abundance of phytoplankton (Rais et al., 2017).

\section{CONCLUSION}

The phytoplankton found in the downstream section of the Musi River consisted of four classes including Bacillariophyceae, Chlorophyceae, Cyanophyceae, and Dinophyceae. The abundance of Bacillariophyceae dominated the waters reaching 
$51.35 \%$ followed by Chlorophyceae $33.58 \%$. The findings also showed that the zooplankton found in the waters consisted of twelve classes with Cilliate as the dominant class reaching $36.56 \%$, followed by Mastigophora $14.7 \%$. The plankton diversity index $\left(\mathrm{H}^{\prime}\right)$ was moderate which means that the waters were moderately to heavily polluted.

The uniformity index (E) was high while the level of dominance (D) indicated that there was no dominant genus found in the waters. The comparison test of ANOVA showed that the abundance of plankton of the stations was not significantly different or in other words, they were the same. Out of the twelve variables tested using PCA, 9 variables were found influencing the abundance of zooplankton: temperature, TDS, TSS, nitrate, nitrite, phosphate, DO, and turbidity. There were four factors which influenced the findings with a total contribution of $82.23 \%$ taken from $37.2 \%, 15.95 \%, 15.7 \%$ and $13.39 \%$. Zooplankton abundance was influenced by four factors with the largest contribution of factor 1 reaching $37.2 \%$ including nitrite, TSS, and phosphate.

\section{REFERENCES}

Adjie, S. (2007). Abundance and diversity of plankton in the downstream section of Musi River.Prosiding Seminar Nasional Forum Perairan Umum Indonesia IV. Pusat Riset Perikanan Tangkap. Badan Riset Kelautan dan Perikanan Jakarta: MA77-MA81.

APHA (American Public Health Association). (1989). Standard Methods for The Examination of Water and Wastewater. American Public Control Federation $20^{\text {th }}$ edition. American Public Health Association, Washington DC, 164pp.

Arazi, R.; Isnaini and Fauziyah. (2019). Community structure and abundance of phytoplankton and their relation to chemical physics parameters in the coastal waters of Banyuasin, Banyuasin Regency. Jurnal Penelitian Sains, 21(1): 1-8.

Aryawati, R.; Bengen, D.G.; Prartono, T. and Zulkifli, H. (2017). Abundance of phytoplankton in the coastal waters of South Sumatera. Ilmu Kelautan, 22(1): 3139.

Aryawati, R.; Ulqodry, T.Z.; Surbakti, H. and Ningsih, E.N. (2018). Skeletonema population in Banyuasin estuary of South Sumatra. Jurnal Ilmu dan Teknologi Kelautan Tropis, 10(2): 269-275.

Asriyana and Yuliana.(2012). Aquatic Productivity. Bumi Aksara, Jakarta, 278pp.

Bahri, S.(2005). Observation of plankton types in the waters of Musi River, South Sumatera. BTL, 6(2): 49-55.

Dewanti, L.P.P.; Putra, I.D.N.N.and Faiqoh, E.(2018). Relationship of phytoplankton abundance and diversity and zooplankton abundance and diversity in the waters of SeranganIsland, Bali.Journal of Marine and Aquatic Sciences, 4(2): 324-335.

Dwirastina, M. and Riani, E. (2019). The composition, abundance, and diversity of phytoplankton in Salah Nama Island, Musi river, South Sumatera. Sainmatika : Jurnal Ilmiah Matematika dan Ilmu Pengetahuan Alam, 16(1): 74-80. 
Eddy, S.(2013). Inventory and identification of fish species during tide in the waters of Musi River, Palembang. Seminar Nasional Sains \& Teknologi V, Lembaga Penelitian Univeristas Lampung, pp.428-436.

Fisheries Ecological Survey Team, Faculty of Fisheries IPB. (1977). Watershed fisheries ecological surveys: the aspects of fisheries rescue in public waters, Directorate General of Fisheries. Agriculture Department of Republik Indonesia, Bogor, 85pp.

Ghozali, I. (2013). The Application of Multivariate Analysis with IBM SPSS 23. Badan Penerbit Universitas Diponegoro, Semarang, 473pp.

Harmoko;and Krisnawati, Y. (2017). Exploration of microalgae species in Lake Aur, Musi Rawas District. Seminar Nasional BIOETI Ke-4 \& Kongres PTTI Ke-12: 250-257.

Irawan, R.; Susanto, R.H. and Ridho, M.R. (2017).The analysis of water quality in the Komering river of Ulak Jermun village Ogan Komering Ilir Distric as the basic for aquaculture management with Keramba system. Jurnal Akuakultur Rawa Indonesia, 5(2): 182-194.

Ismunarti, D.H.(2013). Principal component analysis on the relationship of spatial distribution of phytoplankton communities and environmental factors. Ilmu Kelautan, 18(1): 14-19.

Isnaini; Surbakti, H. and Aryawati, R. (2014).Spatial distribution of phytoplankton in the waters of Bangka Strait.Simposium Nasional Kelautan dan Perikanan, Fakultas Ilmu Kelautan dan Perikanan, Universitas Hasanuddin, Makasar, 1-9.

Kadir, M.A.; Damar, A. and Krisanti, M. (2015). The spatial and temporal dynamics of zooplankton community structure in Jakarta bay. Jurnal Ilmu Pertanian Indonesia, 20(3): 247-256.

Kartika, A.; Hanafiah, Z. and Salni.(2015). A study of plankton communities in Kundur river, Banyuasin I district, Banyuasin Regency, South Sumatera. Jurnal Penelitian Sains, 17(3): 17320-131 - 17320-136.

Meiwinda, E.R.; Marsi and Arinafril.(2015). Plankton community as contamination's bioindicator Musi river in Gandus and Kertapati districs according to tidal. Jurnal Akuakultur Rawa Indonesia, 3(2): 25-35.

Mulyadi, Ulqodry, T.Z.; Aryawati, R.; Isnaini and Surbakti, H. (2019).The characteristic of phytoplankton distribution at Sugihan estuary, South Sumatera. Jurnal Kelautan Tropis, 22(1): 19-26.

Munthe, Y.V.; Aryawati, R. and Isnaini.(2012). Community structure and distribution of phytoplankton in Sungsang waters, South Sumatera. Maspari Journal, 4(1): 122130.

Nybakken, J.W.(1992). Marine Biology; an Ecological Approach (a translation of Eidman M., Koesbiono, Bengen D.G., Hutomo M., Sukardjo S.). Gramedia, Jakarta. 
Odum, E.P. (1996). Ecology Basics. Gadjah Mada University Press, Yogyakarta, 697pp.

Pratama, F.; Rozirwan; and Aryawati, R.(2019). Dynamics of phytoplankton communities during the day and night in the waters of the village of Sungsang, the mouth of Musi River, South Sumatera. Jurnal Penelitian Sains, 21(2): 83-97.

Prianto, E. and Suryati, N.K. (2010). Compositionof species and fish resources potency in estuary of Musi river. Jurnal Penelitian Perikanan Indonesia, 16(1): 1-8.

Prianto, E.; Husnah and Aida, S.N. (2008). Inventory of zooplankton species and ecological structures in the downstream section of Musi River, South Sumatera. Jurnal Penelitian Perikanan Indonesia, 14(3): 263-171.

Prianto, E.; Nurdawaty, S. and Kamal, M.M. (2013). Distribution, abundance and variation in size of fish larvae on Musi river estuary. BAWAL; 5(2): 73-79.

Purnamaningtyas, S.E.; Hedianto, D.A. and Riswanto.(2017). Relations of several physicochemical parameters and phytoplankton in coastal Kubu Raya district, West Kalimantan. Jurnal Ilmu dan Teknologi Kelautan Tropis, 9(2): 727-737.

Rais, A.H.; Rupawan and Herlan. (2017). The correlation between the density of fish and environment condition in estuary waters of Banyuasin Regency. Jurnal Penelitian Perikanan Indonesia, 23(2): 111-122.

Samuel; Adjie, S. and Subagdja.(2013). Inventory and distribution of biota and habitat characteristics of Musi River. Prosiding Hasil-Hasil Riset. Pusat Riset Perikanan Tangkap. Badan Riset Kelautan dan Perikanan. Jakarta, 89-108.

Santoso, S. (2015).SPPS 20: Statistical Data Processing in the Information Age. PT Elex Media Komputindo, Jakarta, 454pp.

Soraya; Hanafiah, Z. and Windusari, Y. (2014). Physical chemistry analysis aquatic to detect water quality Rambang River Ogan Ilir in South Sumatra. Biospecies, 7(2): 43-46.

Supono.(2008). Epipelic diatomic analysis as an indicator of pond environmental quality for shrimp culture. Thesis. Program Studi Magister Manajemen Sumberdaya Pantai, Program Pascasarjana Universitas Diponegoro Semarang, 68pp.

Tabachnick, B.G. and Fidell, L.S. (2019). Using Multivariate Statistics ( $7^{\text {th }}$ ed). Pearson Publisher, New York, 966pp.

Tawanggian, Y.; Sagala, E.P.; and Hannafiah, Z.(2020). Structureof plankton community in the Komering river of Palembang city area South Sumatra. Sriwijaya Journal of Environment, 5(1): 1-8.

Trisnaini, I.; Kumalasari, T.N. and Utama, F.(2018). Identification of river physical habitat and biolytic diversity as indicators of water pollution in Musi River, Palembang. Jurnal Kesehatan Lingkungan Indonesia, 17(1): 1-8.

Ulqodry, T.Z.; Yulisman, Y.; Syahdan, M. and Santoso, S. (2010). Characteristics and distribution of nitrate, phosphate and dissolved oxygen in Karimunjawa waters, Central Java. Jurnal Penelitian Sains, 13(1): 35-41. 
Umar, H.B.(2009). Principal Component Analysis (PCA) and its application by SPSS. Jurnal Kesehatan Masyarakat, 3(2): 97-101.

Wiadnyana, N.N. and Husnah.(2011). Theefforts to manage the waters of Musi River, Sumatra for sustainable use of fish resources. Jurnal Kebijakan Perikanan Indonesia, 3(1): 13-26.

Wibowo, A.; Sunarno, M.T.D. and Makmur, S. (2009). Physical, chemical, and biological parameters characteristic of Belida fish (Chitala lopis) habitat. Jurnal Penelitian Perikanan Indonesia, 15(1): 13-21.

Zulkifli, H.;Husnah; Ridho, M.R.; and Juanda, S. (2009). Quality Status of the downstream section of Musi River in terms of phytoplankton communities. Berkala Penelitian Hayati, 15(1): 5-9.

\section{Regulations}

Decree of Minister of Environment No.15 of 2004on Quality standards of seawater.

Minister of Environment Decree No. 51 of 2004on Sea water quality standard.

Regulation of the Governor of South Sumatera Province No.16 of 2005 on Designation of water and river water quality standards. 